\title{
22
}

\section{Opposition to the Washington Consensus: The IMF and Social Policy Reforms in Post-Soviet Russia}

\section{Heiko Pleines}

\section{Introduction}

In Central and Eastern Europe, the socialist welfare state had established a comprehensive system of social security which was run as part of the planned economy. However, insufficient financial support meant that it increasingly failed to live up to the promised ideal. The situation worsened dramatically when the socialist system collapsed in the late 1980s. The post-socialist states faced what at the time was the worst economic decline ever recorded outside war. While the Central East European countries that would later join the European Union started to recover in the mid-1990s and began to consolidate their social security systems on a lower level, the post-Soviet countries did not. Russia's gross domestic product (GDP), for example, declined by more than 40 percent over the course of the 1990s. As their creditworthiness on international financial markets suffered, these countries increasingly turned to international

\section{H. Pleines $(\bowtie)$}

University of Bremen, Bremen, Germany

e-mail: pleines@uni-bremen.de 
financial institutions, most prominently the International Monetary Fund (IMF), as lender of last resort.

The IMF, in tandem with the World Bank, promoted a set of neoliberal economic policies commonly referred to as the "Washington Consensus". In addition to the general neoliberal policy prescriptions related to free markets and a "lean" state, the IMF strongly focused on the state budget. This was not just the logic of neoliberalism, but also the logic of a bank, as which the IMF in fact acted. In order to ensure that countries with unsustainable debts could repay IMF loans, their budget deficits had to be reduced substantially. As the idea of a lean state-as well as the dire economic situation of the countries turning to the IMFdid not allow for large tax increases, and as privatisation often failed to provide a boost to the budget in the short run, much of the budget balancing the IMF demanded had to be done through spending cuts. Subsidies and spending on welfare were common targets of IMF conditionality. The main aim was to significantly reduce the generosity and degree of inclusion of social policy measures in order to consolidate public finances (Deacon and Hulse 1997).

However, up to the 1980s the IMF had mainly dealt with low-income countries that lacked complex and universal social security systems. As Orenstein $(2008,84-85)$ summarises, for post-socialist countries

the end of subsidies, full employment, and enterprise-based social provision created enormous pressure for welfare-policy reform. Yet neoliberal economic advisors-long used to dealing with developing countries that lacked extensive social policies-largely ignored state welfare programs aside from unemployment insurance (a key element of neoliberal reform programs in Central and Eastern Europe). (...) The neoliberal 'Washington Consensus' was clear on trade policy, market liberalization, and privatization, but had little to say on the social-sector restructuring that was to become such a large part of postcommunist transformation.

As the countries turning to the IMF for loans often did not have any alternative bar default, "the structural adjustment policies of the World Bank and International Monetary Fund (IMF) have long been criticised as a coercive form of economic reform measures" (Stone 2012, 491). 


\section{Russia's Dealings with the IMF}

Russia joined the IMF shortly after the break-up of the Soviet Union and agreed on its first IMF loan just a month later, in July 1992. But already in the following year the IMF suspended its lending programme to Russia, citing insufficient reform measures. The first big IMF loan to Russia was then agreed in 1995 . The 6.8 bn USD loan was the second largest the IMF had made at the time. It was followed by an agreement in 1996 to provide a total of 10.2 bn USD over three years.

However, economic turmoil in Russia reached a climax in 1998. GDP fell by 5 percent in that year. Inflation reached 84 percent. Unemployment stood at 12 percent, while the average monthly wage amounted to a mere 100 USD. The government found it increasingly hard to finance state debts and declared default in August. As a result, the exchange rate of the national currency fell by 60 percent against the USD. Facing default, in July 1998 Russia agreed to a twenty-three bn USD financial package with the IMF and World Bank (Gould-Davies and Woods 1999).

The conditions the IMF demanded prior to the agreement were summarised in a confidential IMF report. They were confirmed by a letter of intent from the Russian government. Both documents have since been declassified. Concerning social policy, the three major demands were to "take measures to restore balance to the Pension Fund", "reduce the overall expenditures of the (Social Insurance) Fund by 25 percent" and "bring the Employment Fund on budget" (IMF 1998b, 4). To achieve these targets, the Russian government promised a substantial reduction in pension payments, while at the same time increasing the respective payroll tax. The cut in spending by the Social Insurance Fund included "eliminating all expenditures that (were) not directly related to providing insurance related benefits (e.g., sick leave or maternity benefits)" (IMF 1998a, 23).

Moreover, the demands by the IMF and World Bank included the restructuring of uncompetitive industries, like coal mining, which would lead to large layoffs. In this context, the Russian government also promised a liberalisation of the labour market, including a law to establish 
a realistic minimum of social guarantees, enhance the role of individual labor agreements, including a more simplified procedure for dissolving individual labor agreements (such as excluding the need for consent of trade unions and the requirement of finding alternative employment) and expand the ability to enter into fixed term and multiple work contracts. (IMF 1998a, 35)

Thus, as Manning $(2003,20)$ stated, "for (...) Russia, the heavy hand of the International Monetary Fund (IMF) made loans and credits dependent on following a liberal ideology in which an American-style residual welfare state was paramount". Such a policy was in sharp contrast to popular expectations, as the population in the post-Soviet countries, including Russia, was still used to comprehensive social support from the state. Of the top five priorities for state spending named in a representative public opinion poll, a total of three were related to social policy, namely healthcare, education and social security payments including pensions. At the same time, two-thirds of the population shared a negative view of the IMF (Levada 2000a), while only 18 percent believed the claim by the Russian government that IMF loans were important to avoid economic collapse (Levada 2000b).

This public mood dominated politics in 1998. In protest, coal miners blocked the country's major long-distance transport links in what was known in Russia as the "rail war". From mid-June until September 1998, coal miners from different regions also protested nonstop in front of the government building in Moscow, demanding the resignation of the president and the government. In October 1998, the biggest opposition party and the Federation of Independent Trade Unions organised a nationwide strike. The government was struggling to find a line. In 1998/1999 the country had six prime ministers. In May 1999 parliament tried to impeach President Boris Yeltsin, who resigned by the end of that year, before his term had officially ended.

Given these circumstances, no parliamentary deputy dared to defend the IMF when legislation addressing its demands was discussed in 1998 and 1999. The left and right of the political spectrum were equally opposed to any cooperation with the IMF, referring to bad advice and even accusing it of intentional destruction. Additionally, they blamed the 
Russian government for collaboration, conspiracy and embezzlement. While deputies from liberal parties had a share of 10 percent in parliament, their share in IMF-related statements stood at only 2 percent. The representatives of the state executive, when appearing in parliament, mostly limited their arguments to the IMF as a source of financial support (Pleines 2021). As a result, many of the original reform plans were not fully implemented.

For example, the draft law "On State Social Benefits" originally offered the option to abolish in-kind social benefits. These benefits were a legacy from the Soviet Union where direct access to goods and services had often been preferred to monetary compensation, as many goods had been in short supply. After the end of the Soviet Union, Russia had continued to introduce in-kind benefits. At the time of the reform debate in the late 1990s national legislation regulated over 150 different forms of in-kind benefits for over 200 different categories of recipients. The most important in-kind benefits were related to transport, healthcare, housing (including reduced utility payments and repair services) and also leisure time and recreational services (from free entry to museums and parks to health resort vouchers). Recipients were defined by three different logics. First, in-kind benefits were provided to those in social need, including pensioners and disabled people. Second, benefits were also provided in return for special services to the country, for example to war veterans or heroes of labour. Third, in-kind benefits were used as bonus payments for public servants. As a result of this complexity, the state could neither establish the number of citizens entitled to support nor the financial costs to the state budget. According to a survey of Russian households financed by the World Bank, a quarter of the population and half of all Russian households were entitled to in-kind benefits. The World Bank estimated the overall costs of the in-kind benefits at around 4 percent of GDP. However, actual costs were much lower as many of the in-kind benefits were in fact not available to those legally entitled to them. Abolishing the in-kind benefits was meant to improve the targeting of social support and at the same time to reduce the costs to the state budget. (The most detailed overview of the system of in-kind benefits is provided by Sinitsina 2008.) 
However, after strong resistance from parliament, the abolishment of in-kind benefits was dropped during the second reading of the law in September 1998. Commenting on the overall anti-crisis measures of the Russian government, the IMF spoke of a "significant step back" from market reforms. Still, Russia managed to get another stand-by credit of 4.5 bn USD from the IMF in July 1999.

\section{Emancipation from the IMF}

The situation changed remarkably in 2000 . The Russian economy saw a long-lasting economic recovery based on strongly rising world market prices for its exports of natural resources. From 1999 to 2008 the country's GDP rose by 7 percent per year on average. In the same period, average monthly wages increased from little more than sixty USD to nearly 700 USD. Unemployment fell from 13 to 6 percent. Russia had fully repaid its debt to the IMF by 2005 .

Vladimir Putin, who had been elected as Russia's president in 2000, swiftly moved to consolidate political power. He managed to marginalise influential business tycoons, regional governors and the political opposition. He used his popularity to implement major reform projects.

In line with a more assertive policy stance, Russia also made a point of being independent of Western aid and advice. This limited engagement manifested itself in many forms. The number of high-level meetings between IMF representatives and the Russian government, for example, which added up to twenty in the period from 1997 to 1999, stood at only one per year after 2004. At the same time, references to policy advice from international organisations all but disappeared from national debates.

\section{The Domestic Approach}

However, this did not mean a break with neoliberal ideas. Putin promoted prominent advocates of economic liberalism to leading positions in the presidential administration and in government. They developed 
several large reform projects, including a comprehensive tax reform, administrative reforms cutting red tape and liberalisation of the land market. In 2003 Putin announced reforms of the social security system.

In 2004, when his party commanded a vote share of 70 percent, it took parliament just three months to pass a law which abolished most in-kind social benefits — a project which had failed six years earlier despite IMF conditionality. The draft law revising each in-kind benefit for each social group entitled to it was over 400 pages long. The main idea was to replace in-kind benefits with cash pay-outs. Thus, in public debates and media reporting the reform was generally called "monetisation of benefits". But as one aim was still to consolidate the state budget, for most of the recipients the monetary compensation fell far short of the value of the in-kind benefits. In fact, the broader aim of the reform was to introduce "logics of cost effectiveness, accountability and transparency" (Wengle and Rasell 2008, 753).

Reform projects like this have led to a reinterpretation of the role of the IMF. Bönker et al. (2002, 5-6) were among the first to realise that it

cannot be said that the neoliberal discourse was forced on the postcommunist countries from the outside, even though the international financial institutions very soon assumed the mandate for overseeing the economic reform process in Eastern Europe. The 'elective affinity' between East European reformers and Western advisers probably runs deeper than is often assumed.

However, despite the government's control over parliament and an improved economic situation, a large part of the Russian population was still strongly opposed to social reforms which reduced benefits. In a representative opinion poll, about half claimed that in their place of living dissatisfaction with the political leadership was growing (Klimov 2010). In January 2005, when the law came into force, demonstrations erupted country-wide, developing into Russia's biggest protest wave of the decade. Again, national and international promoters of the neoliberal reform were ill prepared (Maltseva 2016). The IMF commented: "The fierce resistance to social benefit reforms had come as a surprise and was tempering the pace of further reforms in the social area" (IMF 2005, 25). 
After a period of silence, Putin publicly criticised the reform. The government reacted with an increase in pensions, guaranteed discounts on public transport for recipients of in-kind benefits and a delay of further social reforms. The responsibility for in-kind benefits was transferred to the regional level. While this helped to diffuse public anger, it increased social inequalities between Russia's regions as their resources for the provision of social support measures differ widely (Sinitsina 2008).

\section{Conclusions}

The Russian debate of 1998 demonstrates how toxic IMF involvement in domestic politics can become. Although in its self-perception the IMF was about to save Russia, it could not command a single supporter of its policy in the Russian parliament. The IMF was, of course, aware of the problems faced by the governments it was dealing with. Though the initial conditionality was very strict, its implementation was rather pragmatic. The case of Russia is typical in this respect. Though many of the IMF conditions had not been met in 1998, a new loan was nevertheless agreed in 1999. Moreover, it came with an understanding that cuts to social spending were not desirable.

The problem with this pragmatism on the part of the IMF was and still is that, first, national governments do not really know which conditions are negotiable. As a result, loan agreements become much less predictable. Second, the IMF often only retreats after the damage, in the form of popular protests, has already been done. The room for manoeuvre of national governments is much smaller by then. Moreover, the IMF loan may be too late. Russia received the new loan only after its default had already plunged the country into turmoil.

In the early 2000s, the conciliatory approach was summarised as the "post-Washington consensus". The former chief economist of the World Bank, Joseph Stieglitz (2008, 53-54), named as key elements the involvement of local actors and their ideas, the consideration of local circumstances instead of a "one size fits all" policy, the need to strengthen states' regulatory capacity as well as the market, and also the idea that success goes beyond purely economic indicators. 
The second part of Russia's experience, however, clearly illustrates that the IMF may sometimes not be the cause of neoliberal reforms, but rather a scapegoat. National governments can be as zealous in their pursuit of neoliberal policies as the IMF. Russia's domestic policymakers in the economic and social sphere were highly influenced by the Washington Consensus. Accordingly, they continued to promote neoliberal policies even when the country's relation with the IMF had already cooled down.

Acknowledgements This chapter is a product of the research conducted in the Collaborative Research Center "Global Dynamics of Social Policy" at the University of Bremen. The centre is funded by the Deutsche Forschungsgemeinschaft (DFG, German Research Foundation)—project number 374666841-SFB 1342.

\section{References}

Bönker, Frank, Klaus Müller, and Andreas Pickel. 2002. Cross-Disciplinary Approaches to Postcommunist Transformation: Context and Agenda. In Postcommunist Transformation and the Social Sciences: Cross-disciplinary Approaches, ed. Frank Bönker, Klaus Müller, and Andreas Pickel, 1-37. Lanham, MD: Rowman and Littlefield.

Deacon, Bob, and Michelle Hulse. 1997. The Making of Post-Communist Social Policy: The Role of International Agencies. Journal of Social Policy 26 (1): 43-62.

Gould-Davies, Nigel, and Ngaire Woods. 1999. Russia and the IMF. International Affairs 75 (1): 1-22.

IMF. 1998a, July 16. Russian Federation-Letter of Intent. To Members of the Executive Board, Document of International Monetary Fund and not for public use, Confidential, EBS/98/120.

. 1998b, July 20. Russian Federation-Use of Fund Resources-Request for Augmentation of Extended Arrangement and Request for Purchase Under the Compensatory and Contingency Financing Facility. To Members of the Executive Board, Document for International Monetary Fund and not for public use, Confidential, EBS/98/120, Supplement 2. 
- 2005, August 17. Russian Federation-Staff Report for the 2005 Article IV Consultation. To Members of the Executive Board, Document for International Monetary Fund and for official use only, SM/05/321.

Klimov, I. 2010. Reforma Sotsial'nykh l'got v Otsenkakh Rossiyan (Reforms of Social Benefits in the Assessment of the Russian Population). Journal of Social Policy Studies 4 (3): 295-318.

Levada. 2000a. Obshchestvennye Nastroyenie v Rossii (Public Sentiment in Russia). Opinion poll. Retrieved March 11, 2021, from https://www.levada. ru/2000/10/05/obshhestvennye-nastroeniya-v-rossii-v-sentyabre-2000/

2000b. Zaimy ot MVF (Loans from the IMF). Public opinion poll, 2000. Retrieved March 11, 2021, from https://www.levada.ru/2000/04/20/ lenin-radosti-i-ogorcheniya-zajmy-ot-mvf-putin-i-vybory-gubernatora-vpeterburge/

Maltseva, Elena. 2016. Framing a Welfare Reform: The Social Benefits Reform in Russia and Kazakhstan. Canadian Slavonic Papers 58 (3): 229-256.

Manning, Nick. 2003. The Transferability of Welfare Models between East and West. Cross-National Research Papers 7 (1): 19-30.

Orenstein, Mitchell. 2008. Postcommunist Welfare States. Journal of Democracy 19 (4): 80-94.

Pleines, Heiko. 2021. The Framing of IMF and World Bank in Political Reform Debates: The Role of Political Orientation and Policy Fields in the Cases of Russia and Ukraine. Global Social Policy, 21 (1): 34-50.

Sinitsina, Irina. 2008. Experience in Implementing Social Benefits Monetization Reform in Russia. Literature Review. CASE Network Studies \& Analyses, No. 381.

Stieglitz, J.E. 2008. Is There a Post-Washington Consensus? In The Washington Consensus Reconsidered: Towards a New Global Governance, ed. Narcis Serra and Joseph E. Stieglitz, 41-56. Oxford: Oxford University Press.

Stone, Diane. 2012. Transfer and Translation of Policy. Policy Studies 33 (6): 483-499.

Wengle, Susanne, and Michael Rasell. 2008. The Monetisation of l'goty: Changing Patterns of Welfare Politics and Provision in Russia. Europe-Asia Studies 60 (5): 739-756. 
Open Access This chapter is licensed under the terms of the Creative Commons Attribution 4.0 International License (http://creativecommons.org/licenses/ by/4.0/), which permits use, sharing, adaptation, distribution and reproduction in any medium or format, as long as you give appropriate credit to the original author(s) and the source, provide a link to the Creative Commons licence and indicate if changes were made.

The images or other third party material in this chapter are included in the chapter's Creative Commons licence, unless indicated otherwise in a credit line to the material. If material is not included in the chapter's Creative Commons licence and your intended use is not permitted by statutory regulation or exceeds the permitted use, you will need to obtain permission directly from the copyright holder.

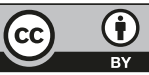

